\title{
"Somos Índios da Tribo Tuxá Nação Proká Pragaga do Arco e Flecha e Maracá Malacutinga Tuá Deus do Ar"
}

Jandair Ribeiro de Oliveira*

Vou contar uma história que, diferentemente das outras, não irá começar com o "Era uma vez". E para você saber o porquê basta acompanhar essa viagem com o seu coração, e juntos iremos descobrir a verdadeira essência do que é ser índio Tuxá, como é viver feliz, cultivar o amor, respeitando o próximo como a si mesmo, vivendo no mundo com a força de Tupã.

Meus parentes indígenas ou não,

Como contar essa linda história sem

Estar tomado pela emoção.

Sou do rio, ribeirinho sou Tuxá

E no Rio São Francisco do outro lado de lá

Encontrei o meu lugar, a minha nação Proká

Rua Felipe Camarão, Ilha da Viúva vou recordar

Morada ao pé da serra que os caboclos

A índia bem pequenininha mandou chamar.

A nossa raiz está no Sorobabel, está na arte do rio

Enfrentando cachoeiras, descendo e subindo o rio

És ilha, alimento, paraíso, natureza, encanto e canto do rio.

Capitão João Gomes Apax Caramuru é raiz

Manuel de Souza é raiz

Os tuxá sabem quem são essas raízes

E por isso nossa árvore tem raiz.

* Graduado em Pedagogia pela Universidade Estadual de Feira de Santana (UEFS). E-mail: jandairribeiro@hotmail.com 
Vivenciamos as frentes pastoris, missionárias

Nossa aldeia surgiu de uma dessas missões

A São João Batista de Rodelas, onde diferentes povos

Deram origem ao povo Tuxá.

Karirí, Acará, Karuru, Xucuru

E a nossa voz Procá calada pelo chegar

Curraleiros, colonizadores, latifundiários da Casa da Torre, religiosos

Todos passaram por cá, e hoje marcas tristes ainda temos que curar.

Capitão Francisco Rodelas deu nome ao lugar

Sua bravura e coragem fizerem o povo prosperar

Avisa capitão o dilúvio está chegando

O destino desse povo agora está em pranto

Não vou falar desse fato agora

A vida antes era tão boa que não cabe a tristeza agora

Meu Cari, meu Piau, meu Surubim, minha batata doce.

Minha capivara, camaleão muitas caças

Acompanhadas de contos de diversão.

Hoje com boa parte da fauna e flora destruída

Digo a você "Progresso"

Você quase que acaba com a minha vida

Eu tinha a minha roça a minha cebola e fartura de montão

Tinha canoa, barco a motor, a vela e a remo

Avistava meu serrote encantado ao extremo

Na ilha tinha trabalho, as lendas e visões

Meu canto tem o Velho Chico e o Serrote

Meu São João Batista, por favor, me acode

Protetor dos Tuxá que faz da nossa cultura

A religião católica e a crença indígena se misturar

Oi cabocla do mato só vem folgar

O toré e a jurema chamam os encantados

E vamos todos regimar.

Vou dançando com meu canto entoando

Meus antepassados escutam meu maracá

Levanta o espírito tuxá que a coragem e alegria há de chegar 
É só pisar o Toré com força e animação para receber a benção

Minha árvore sagrada é a jurema

Com ela faço o meu ritual o "particular".

Que é o ponto forte da ciência Tuxá.

O contato com o homem branco

Fez até a nossa igreja se descolar

Se antes era voltada para a nossa aldeia

Agora para os invasores ela está a olhar

De protagonistas a coadjuvante da história local

Passamos a ficar, e até a minha casa eu a vi inundar

Nosso São João Batista continua a nos olhar

Acompanhando todas as mudanças

Enfrentadas pelos Tuxá.

Nossa cultura está cada vez mais forte

Da forma que o mundo está

Tentando nos iludir, mas sabemos ir e voltar

Não importa o meu rosto, minha roupa, o meu cabelo

O que vale é ser para sempre um Tuxá guerreiro.

A inundação ocorreu em 1987

Tristeza, desolação e abandono

Tuxá teve que enfrentar

Com lágrimas e sangue derramando.

E, no entanto, as águas da Barragem

A nossa cultura não conseguiu inundar.

Hoje tem a divisão que nos causa frustração

Tem tuxá em Rodelas, Ibotirama, Banzaê e Inajá

A distância não importa quando sabemos lutar

Lutar por dias melhores e para a união reinar.

Depois de 22 anos da mudança para um novo território

No início dificuldades tivemos que enfrentar

Mas para os Tuxá nada é impossível e pode o aterrorizar

Organizar a vida e se adaptar são feitos históricos

Que a sociedade deve olhar com outro olhar

Não ficamos civilizados nem educados da forma deles

Apenas aprendemos o que nos é necessário para não ser inferior a eles

Nesse mundo infestado de injustiças e violências sem fim

O meu patrimônio nunca irão destruir

Minha identidade e tradição 
Que muitos como uma estaca no peito

Perderam a noção que o melhor da vida

É ser o que manda o seu coração de um Tuxá.

Que bom que moramos juntos

Que bom que estamos na luta com os nossos parentes

Que bom que respeitamos o íntimo do ser humano

Que bom que temos os mais velhos sábios, de conhecimentos sem fim.

Que bom que na nossa aldeia tem mulheres guerreiras

Que bom que temos crianças e jovens apaixonados pela nossa cultura

Que bom que temos mostrado para o mundo que os Tuxá

Têm consciência que não há como mudar o início da história

Ou viver sem denunciar as mazelas sofridas pelos indígenas

Nós não podemos mudar o começo

Mas o que se tem visto é que os Tuxá estão construindo

Um novo fim,

De realizações, vitórias, sonhos reais, construção coletiva, parcerias, integridade, solidariedade, humanismo, sabedoria, conquistas, respeito, amor à causa, enfim amor à vida do Indígena.

Jandair Ribeiro de Oliveira - Tuxá. 